\title{
Occurrence and settlement of the common shipworm Teredo navalis (Bivalvia: Teredinidae) in Bremerhaven harbours, northern Germany
}

Received: 15 August 2001 / Revised: 25 January 2002 / Accepted: 28 January 2002 / Published online: 18 April 2002

(C) Springer-Verlag and AWI 2002

\begin{abstract}
The shipworm Teredo navalis L. is a xylophagous bivalve mollusc (Bivalvia: Teredinidae) with a long record of being very destructive to wooden ships and harbour buildings. It has been reported from numerous sites at the coasts of both the North and Baltic Seas since the eighteenth century. Here, we document for the first time the occurrence of live adult T. navalis in the harbours of Bremerhaven (Weser estuary, northern Germany). From August to December 1998, various wooden structures (fir floating fenders and pier posts, oak piles) from seven stations in different docks of two harbours (Überseehafen, Fischereihafen) were investigated for the presence and density of live specimens and burrows of $T$. navalis. The settlement of larval shipworms was studied by exposing experimental fir panels $0.06 \mathrm{~m}^{2}$ in size at 20 stations at water depths between 1 and $2 \mathrm{~m}$ for periods of 4 months between July and November. In addition, hydrographic profiles ( $0-8 \mathrm{~m}$ water depth) were obtained at 17 stations in five docks once every month from August to December. Live adult shipworms were found in both fir floating fenders and oak piles at four stations. The largest specimen found was $250 \mathrm{~mm}$ long. Shipworm burrows were detected at five stations in almost every wooden structure investigated but their abundances differed significantly: Maximum values were $>10,000 \mathrm{~m}^{-2}$ in fir floating fenders, $4,600 \mathrm{~m}^{-2}$ in oak piles and $200 \mathrm{~m}^{-2}$ in fir pier posts. Actual shipworm infestation was detected at three of 16 stations in the exposed fir
\end{abstract}

Communicated by H.-D. Franke

U. Tuente $\cdot$ D. Piepenburg $(\varpi) \cdot$ M. Spindler

Institut für Polarökologie, Universität Kiel,

Wischhofstrasse 1-3, Geb. 12, 24148 Kiel, Germany

e-mail: dpiepenburg@ipoe.uni-kiel.de

Tel.: +49-431-6001200, Fax: +49-431-6001210

U. Tuente

Küstenökologische Forschungsgesellschaft $\mathrm{GmbH}$

Alte Deichstrasse 39, 27612 Loxstedt, Germany

U. Tuente

Hansestadt Bremisches Hafenamt Bremerhaven,

Bussestrasse 27, 27570 Bremerhaven, Germany panels (1-3 burrow holes per panel). Water temperatures and salinities varied considerably during the 4-month investigation period. Temperatures decreased from $19.9^{\circ} \mathrm{C}$ in August to $0.7^{\circ} \mathrm{C}$ in December. Salinities ranged from 17.6 in August to 1.1 in November, but only at two lock stations during November and December did value drop below 5 , which is regarded as the lethal limit for the larvae of this euryhaline teredinid species. We conclude that $T$. navalis encounters favourable conditions for growth and reproduction in the harbours of Bremerhaven, at least during summer and autumn, and is a common element of the harbour ecosystem. Therefore, a persistent infestation of all wooden structures after a relatively short period of time seems to be highly probable.

Keywords Harmful invaders - Teredo navalis - Harbour docks $\cdot$ Bremerhaven

\section{Introduction}

Shipworms are marine bivalve molluscs of the family Teredinidae which comprises about 80 species. Adults are specialised to bore into wood and are xylophagous, i.e. they exclusively or primarily feed on wood particles (Turner 1966). Their two shells, enclosing only the front end of the bodies, function as a tool rather than a protective covering; their ridged and roughened surfaces are used for boring. The lockable burrows, which are lined with a calcareous coating produced by the mantle, are begun when the pelagic veliger larvae infest wooden substrates, and are expanded as the animals grow. Shipworms rank among the most prominent alien harmful invaders unintentionally introduced to Europe by ship ballast water releases (Gollasch 1996). There is a general world-wide trend that their population sizes and distribution ranges have increased as their long-range dispersal is favoured by the growth of global ship-borne trade traffic (Reise et al. 1999).

The common shipworm of the north Atlantic, Teredo navalis L., is known to have occurred on the coasts of 
northern Germany since at least the eighteenth century (Woltmann 1751, cited in Kühl 1972). It is a euryhaline species that tolerates low salinities and invades estuarine environments (van Benthem-Jütting 1943). The pelagic larvae survive at salinities as low as 5 (Hoagland 1986), successful spatfall on wooden substrates has been reported at salinities above 10 (Soldatova 1961). Adults may grow up to body lengths of $45 \mathrm{~cm}$, although their shells remain only $12 \mathrm{~mm}$ long (Kaestner 1993). In case of mass occurrences, $T$. navalis has caused significant commercial damage due to the destruction of wooden ships and harbour buildings (Sordyl et al. 1998). Although different deterrent methods have been developed, control is still a problem (Nair and Saraswathy 1971).

Although T. navalis has been reported in the scientific literature from numerous sites along the coasts of both the North and Baltic Seas, it was thought not to be present in the harbours of Bremerhaven, located in the estuary of the river Weser (northern Germany) (Roch 1927; Hahn 1956). Its absence was attributed to the rather low and variable salinities in the dock waters. To test the validity of this hypothesis, different wooden structures from various sites in the locks and docks of two Bremerhaven harbours were for the first time scientifically investigated for the presence and density of both shipworm burrows and live adults. Moreover, the spatfall of larval shipworms was studied by exposing wood substrates for a given period of time and by recording the temperature and salinity dynamics in the harbour waters.

\section{Materials and methods}

Study area

The city of Bremerhaven lies within the meso-haline (brackishwater) zone of the Weser estuary on its south-eastern bank (Kühl 1968). There are two harbour districts: the Überseehafen (overseas harbour), built in 1827 and subsequently enlarged to its current size since 1939, and the Fischereihafen (fisheries harbour), constructed from 1857 to 1925 (Petersen 1996). Their total area is $2.25 \mathrm{~km}^{2}$, and both have an average water depth of $7 \mathrm{~m}$, compared to the present-date water level of the docks. Since the harbour docks are lock-controlled, the water temperature and salinity regimes are less influenced by the tides and, hence more stable, in the docks than outside in the river Weser (Brockmann-Lehe 1914). However, prior to our measurements in 1998 , the sole accurate salinity data available for the harbours of Bremerhaven were those published by Brockmann-Lehe (1914). Values fell into a range between 1 and 17.5.

Sampling

The investigation on the occurrence, distribution and living conditions of T. navalis in the harbours of Bremerhaven was carried out from July to December 1998. To document potentially different hydrographic regimes in the harbours, the sampling stations were distributed in both watergates and various docks (in different distances from the watergates) of both the Überseehafen and the Fischereihafen (Fig. 1).

Once each month from August to December, hydrographic depth profiles were obtained at 17 stations in three watergates and two docks (Fig. 1). Water temperature and salinity were measured at $0.5 \mathrm{~m}$ intervals between the surface and $8 \mathrm{~m}$ water depth (maxi- mum) using a WTW probe (Tetracon 96 A). At each station, three replicate measurements were made.

From August to December, various wooden structures (floating fenders, piles, pier posts) were investigated at seven stations in both watergates and docks for the presence and density of live specimens and burrow holes of T. navalis (Fig. 1). Floating fenders consist of nine hexahedral planks of untreated fir wood $(0.25 \times 0.25 \times 3.20 \mathrm{~m})$, which are bolted together. A total of six floating fenders were studied, which had been in use in the watergates of the Überseehafen (five in the Kaiserschleuse, one in the Nordschleuse) for about 4 years but were brought out of the water for maintenance and repair. From each of the four corner planks of the nine-spar arrays, four $0.05 \mathrm{~m}$-thick wood slices were taken at $0.6 \mathrm{~m}$ intervals along the plank. Piles are untreated but de-barked oak trunks of about $0.4 \mathrm{~m}$ diameter and $8 \mathrm{~m}$ length, which serve during the landing of ships in the locks. These trunks are usually thrust $3 \mathrm{~m}$ into the harbour bottom. Two recently dislodged piles which had been in use for about 20 years - one in the northern watergate (Nordschleuse) and the other in the north-western dock of the Überseehafen - were probed by taking three replicate wood samples $(0.3 \times 0.05 \times 0.1 \mathrm{~m})$ at distances between 1 and $4.5 \mathrm{~m}$ above the sea bottom and separated by intervals of $0.5 \mathrm{~m}$. Pier posts are untreated fir trunks about $0.35 \mathrm{~m}$ in diameter, which had been thrust into the harbour bottom during the construction of the wharves. Some of them have been in use for about 100 years. At three stations in the Fischereihafen, three contiguous piles, standing about $2 \mathrm{~m}$ apart, were probed in situ. From each pile, scuba divers took wood samples $(0.2 \times 0.1 \times 0.05 \mathrm{~m})$ at 1 and $3 \mathrm{~m}$ above the harbour bottom.

The settlement of larval shipworms in 1998 was studied by exposing experimental panels of $0.06 \mathrm{~m}^{2}$ untreated fir wood $(0.3 \times 0.2 \times 0.05 \mathrm{~m})$ for a given period of time (Table 1$)$. At 16 stations in various locks and docks, at locations corresponding to

Table 1 Exposure of experimental fir panels in the harbours of Bremerhaven in 1998. Floating panel racks: single panels fixed at one rack (Single) or three panels fixed at one rack (Triple) floating in a water depth of $1.50 \mathrm{~m}$. Fixed panels: single panels counted on pier posts at water depths of $1 \mathrm{~m}$ and $3 \mathrm{~m}$ above the sea bottom. - indicates loss of racks, (number in brackets) indicates number of lost racks

\begin{tabular}{|c|c|c|c|c|c|}
\hline \multirow[t]{2}{*}{ Location } & \multirow[t]{2}{*}{ Station } & \multicolumn{2}{|l|}{ Date of } & \multicolumn{2}{|c|}{ Number of panels } \\
\hline & & Exposure & Retrieval & Single & Triple \\
\hline \multicolumn{6}{|c|}{ Floating panel racks } \\
\hline Nordschleuse & NS & 31.07 & - & & $3(3)$ \\
\hline Doppelschleuse & DS & 22.07 & - & $2(2)$ & \\
\hline Überseehafen & $\begin{array}{l}\ddot{U} 1 \\
\ddot{U ̈ 2} \\
\ddot{U} 3 \\
\ddot{U} 4 \\
\ddot{U ̈ 5} \\
\ddot{U} 6 \\
\ddot{U} 7\end{array}$ & $\begin{array}{l}22.07 \\
22.07 \\
22.07 \\
22.07 \\
22.07 \\
22.07 \\
22.07\end{array}$ & $\begin{array}{l}11.11 \\
11.11 \\
11.11 \\
11.11 \\
11.11 \\
11.11 \\
-\end{array}$ & $\begin{array}{l}3 \\
3(1) \\
3 \\
3\end{array}$ & $\begin{array}{l}3 \\
3 \\
3\end{array}$ \\
\hline Fischereihafen & $\begin{array}{l}\text { F1 } \\
\text { F2 } \\
\text { F3 } \\
\text { F4 } \\
\text { F5 } \\
\text { F6 } \\
\text { F7 }\end{array}$ & $\begin{array}{l}23.07 \\
23.07 \\
23.07 \\
23.07 \\
23.07 \\
23.07 \\
23.07\end{array}$ & $\begin{array}{l}10.11 \\
10.11 \\
10.11 \\
10.11 \\
10.11 \\
10.11 \\
10.11\end{array}$ & $\begin{array}{l}1 \\
3\end{array}$ & $\begin{array}{l}3 \\
3 \\
3 \\
3 \\
3 \\
\\
3\end{array}$ \\
\hline \multicolumn{6}{|l|}{ Fixed panels } \\
\hline Fischereihafen & $\begin{array}{l}\mathrm{F} 2 \\
\mathrm{~F} 3 \\
\mathrm{~F} 5 \\
\text { Ü5 }\end{array}$ & $\begin{array}{l}10.09 \\
10.09 \\
10.09 \\
20.08\end{array}$ & $\begin{array}{l}30.11 \\
30.11 \\
03.12 \\
26.11\end{array}$ & $\begin{array}{l}2 \\
2 \\
2 \\
2\end{array}$ & \\
\hline
\end{tabular}


Fig. 1 Positions of sampling stations and occurrence of the common shipworm Teredo navalis in two harbour districts (Überseehafen and Fischereihafen) of Bremerhaven in 1998. Inverted triangles indicate location of hydrographic depth profiles; wooden structures probed: with adult shipworms (solid diamonds), without adult shipworms (hollow diamonds); exposed fir panels: with spatfall (solid circles), without spatfall (hollow circles)

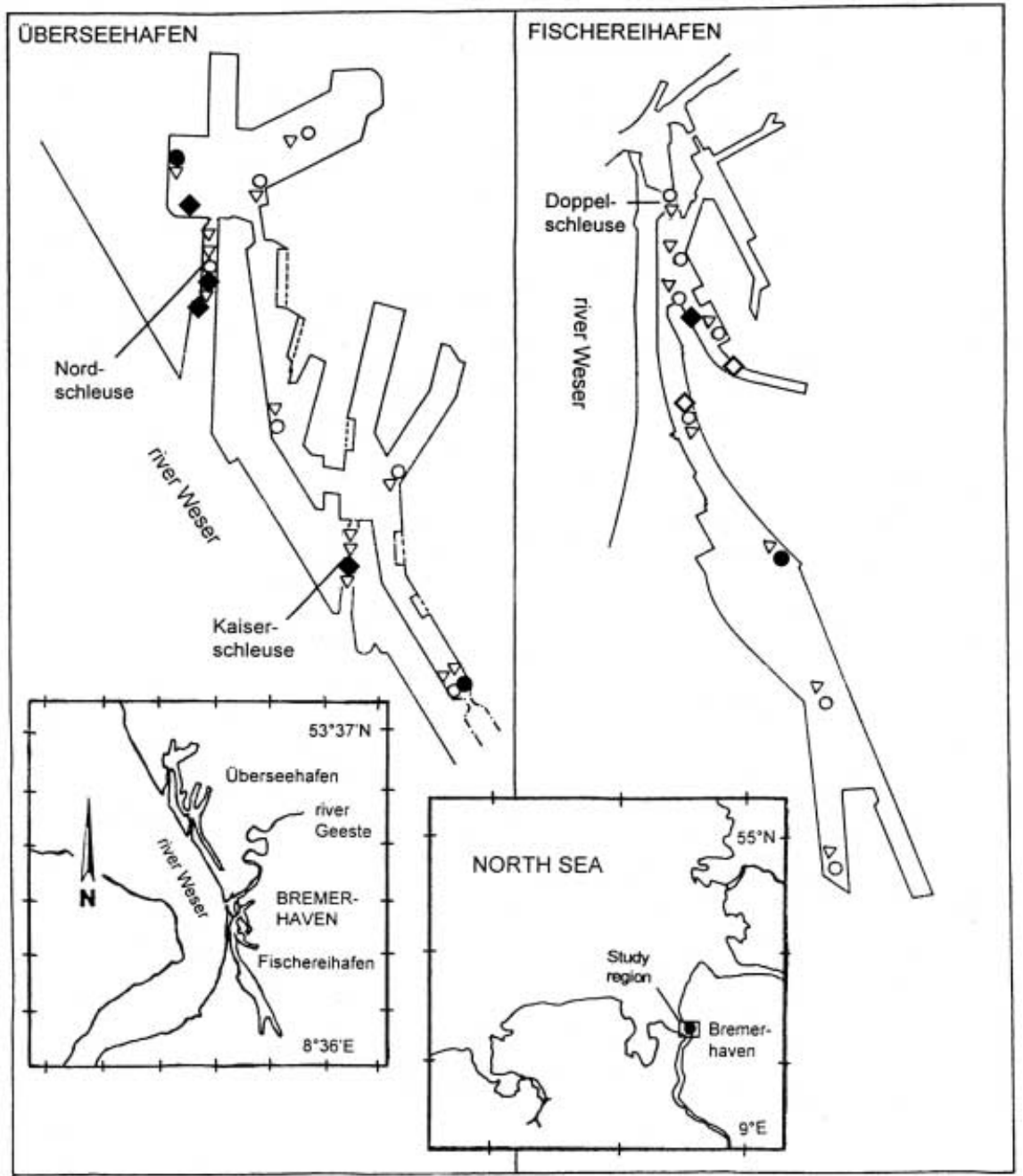

those of the hydrographical measurements (Fig. 1), free floating racks with either one or three replicate panels, $0.2 \mathrm{~m}$ apart, were exposed in a water depth of $1.5 \mathrm{~m}$ from the end of July until midNovember. At four additional stations, three replicate panels were mounted on three different pier posts (approximately $1 \mathrm{~m}$ apart) at water depths of 1 and $3 \mathrm{~m}$ from mid-September until the end of November.

\section{Analyses}

Replicate measurements of water temperature and salinity were averaged. From these within-station means, median values were computed across $0.5 \mathrm{~m}$ depth horizons, separately for each month and each dock and lock.

Shipworm specimens were determined to species level using the keys given by Turner $(1966,1971)$.

Following the approach previously applied by Hahn (1956), Kühl (1957) and Schütz (1961), the numbers, diameters and depths of shipworm tubes recorded in an area of defined size (here $0.01 \mathrm{~m}^{2}$ ) was used to quantify the abundance of adult shipworms. Median values were computed from tube counts of replicate wood samples. The significance of differences of burrow counts among types and between upper and lower floating fender spars was tested using the Kruskal-Wallis test (Sachs 1982).

The actual shipworm spatfall was studied by applying the approach previously used by Ghobashy and Hassan (1980), Kühl (1957), Santhakumari and Nair (1984), Sordyl et al. (1998), and Tsunoda (1979), i.e. by counting shipworm boreholes on the ex- posed surfaces of the fir panels. Each panel was monitored once each month between August and November. The upper halves of the panels were freed from epibionts and investigated for boreholes using a magnifier; the lower halves were also examined, but to study any difference in spatfall with and without fouling, epibionts were not removed; thereafter, the panels were again exposed. After the end of the 4-month exposure period all panels were retrieved and shipworm boreholes were counted in the laboratory. In addition, X-ray photographs were taken to measure the lengths of burrows and bodies of newly settled shipworms (Crisp et al. 1953).

\section{Results}

\section{Hydrography}

Both water temperatures and salinities varied considerably with time during the 4-month investigation period. Temperatures decreased from a maximum of $19.9^{\circ} \mathrm{C}$ in August to a minimum of $0.7^{\circ} \mathrm{C}$ in December; monthly median values ranged from 2.8 to $19.2^{\circ} \mathrm{C}$ (Fig. 2). Within months, there were no significant differences between stations and water depths. Salinity values fell into the range between oligo-haline and meso-haline conditions; 
Fig. 2 Monthly temperature depth profiles in a watergate (Doppelschleuse) and a dock (Fischereihafen) in Bremerhaven harbours in 1998

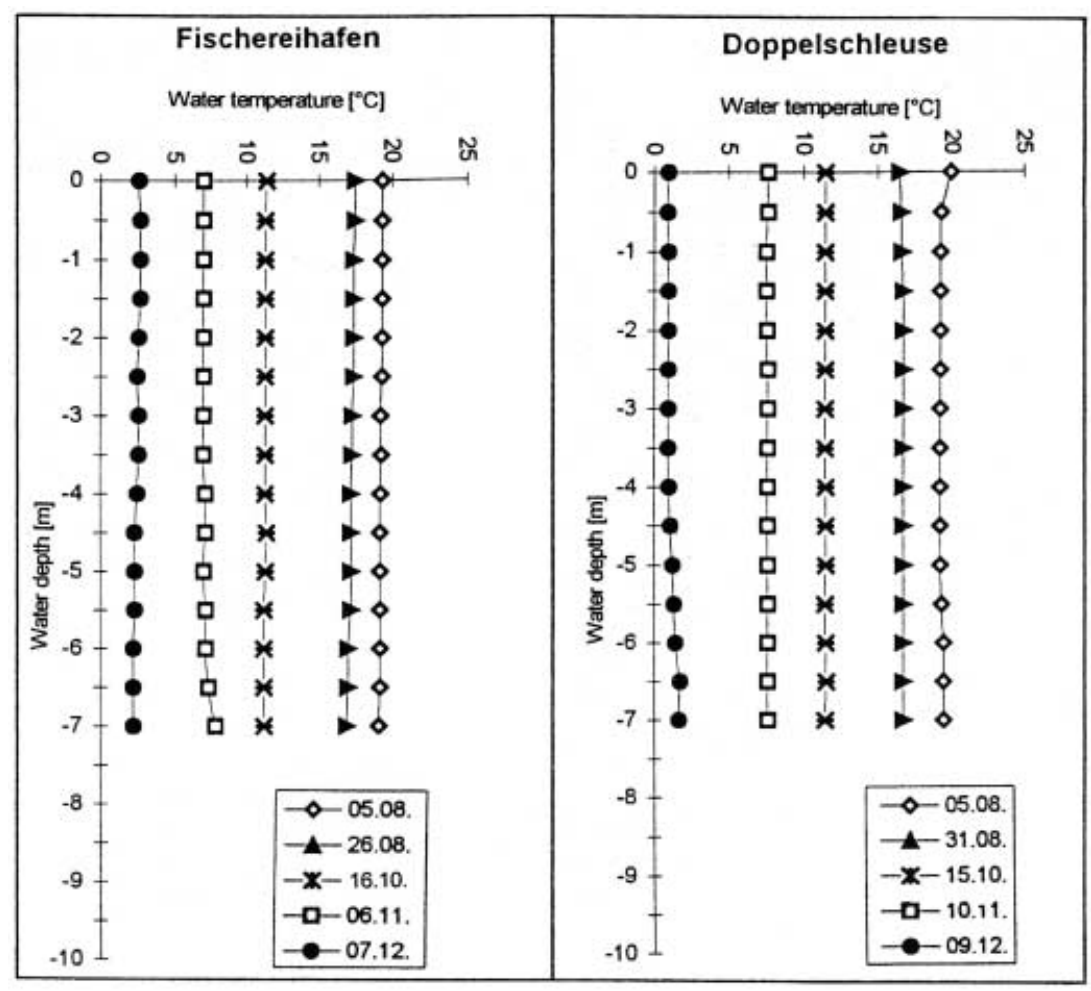

i.e. they ranged from a maximum of 17.6 in August to a minimum of 1.1 in November (Fig. 3). Median values were always in the meso-haline domain (5-14). Only at two lock stations in November and December did minimum values drop below 5, which is regarded as the lethal lower limit of this euryhaline teredinid species.

Distribution and abundance

in existing wooden harbour structures

Shipworm burrows were detected at five stations in almost every wooden structure investigated (Fig. 1). The tubes were up to $250 \mathrm{~mm}$ long and had diameters between 1 and $10 \mathrm{~mm}$. They extended from the wood surfaces up to $100 \mathrm{~mm}$ into the wood.

Morphological analyses of shell plates found in empty burrows showed that all were produced by the same species, Teredo navalis L. 1758. Live adult specimens occurred at a total of four stations in both fir floating fender spars and oak piles. The largest shipworm found was $250 \mathrm{~mm}$ long. One specimen was a larvae-bearing female of $50 \mathrm{~mm}$ length.

Burrow densities differed considerably between the different wooden structures: Maximum values were $>10,000 \mathrm{~m}^{-2}$ in fir fender spars (Figs. 4, 5), 4,600 $\mathrm{m}^{-2}$ in oak piles (Table 2) and $200 \mathrm{~m}^{-2}$ in fir pier posts (Table 2). The differences between the structures at comparable depths (fenders-lower trunks; piles - 2.5 to $3.5 \mathrm{~m}$ above harbour bottom; pier posts $-3 \mathrm{~m}$ above harbour bottom) were significant (Kruskal-Wallis test, $n=56, P<0.001)$.
Table 2 Shipworm tube densities (number $\mathrm{m}^{-2}$ ) in oak piles and fir pier posts in the harbours of Bremerhaven in 1998. Oak piles from one dock of the Überseehafen (three sides of the pile: sides $a, b, c)$ and the northern watergate (Nordschleuse). Fir pier posts from one dock of the Fischereihafen (three posts at station F2: pier posts $1,2,3)$, station code in brackets, - indicates no probing

\begin{tabular}{lrrrl}
\hline $\begin{array}{l}\text { Water depth } \\
\text { (m above sea } \\
\text { bottom) } \\
\text { Oak piles }\end{array}$ & $\begin{array}{l}\text { Shipworm tube density } \\
\left.\text { (number } \mathrm{m}^{-2}\right)\end{array}$ & \\
\cline { 2 - 4 } & Überseehafen NS V & \multicolumn{2}{l}{$\begin{array}{l}\text { Nordschleuse } \\
\text { NS }\end{array}$} \\
\cline { 2 - 4 } & Side a & Side b & Side c & \\
\hline 4.5 & 0 & 0 & 100 & - \\
4.0 & 300 & 300 & 200 & - \\
3.5 & 1,100 & 1,200 & 0 & - \\
3.0 & 1,000 & 2,500 & 100 & 600 \\
2.5 & 900 & 2,300 & 300 & 500 \\
2.0 & 3,900 & 1,700 & 0 & 300 \\
1.5 & 4,600 & 1,900 & 0 & 400 \\
1.0 & 1,800 & 400 & 100 & 400 \\
0.5 & - & - & - & 300 \\
\hline
\end{tabular}

Fir pier posts Fischereihafen (F2)

Pier post 1 Pier post 2 Pier post 3

\begin{tabular}{rrrr}
\hline 3.0 & 100 & 200 & 100 \\
1.0 & 0 & 100 & 0 \\
\hline
\end{tabular}

Besides the obvious differences between the different wooden structures, burrow abundances also showed a clear vertical trend. In floating fenders, they were significantly higher in the lower than in the upper fir planks (Fig. 4; Kruskal-Wallis tests, $P<0.05$ ). Along the oak pile 
Fig. 3 Monthly salinity depth profiles in two different watergates (Nordschleuse, Doppelschleuse) and two docks

(Überseehafen, Fischereihafen) in Bremerhaven harbours in 1998

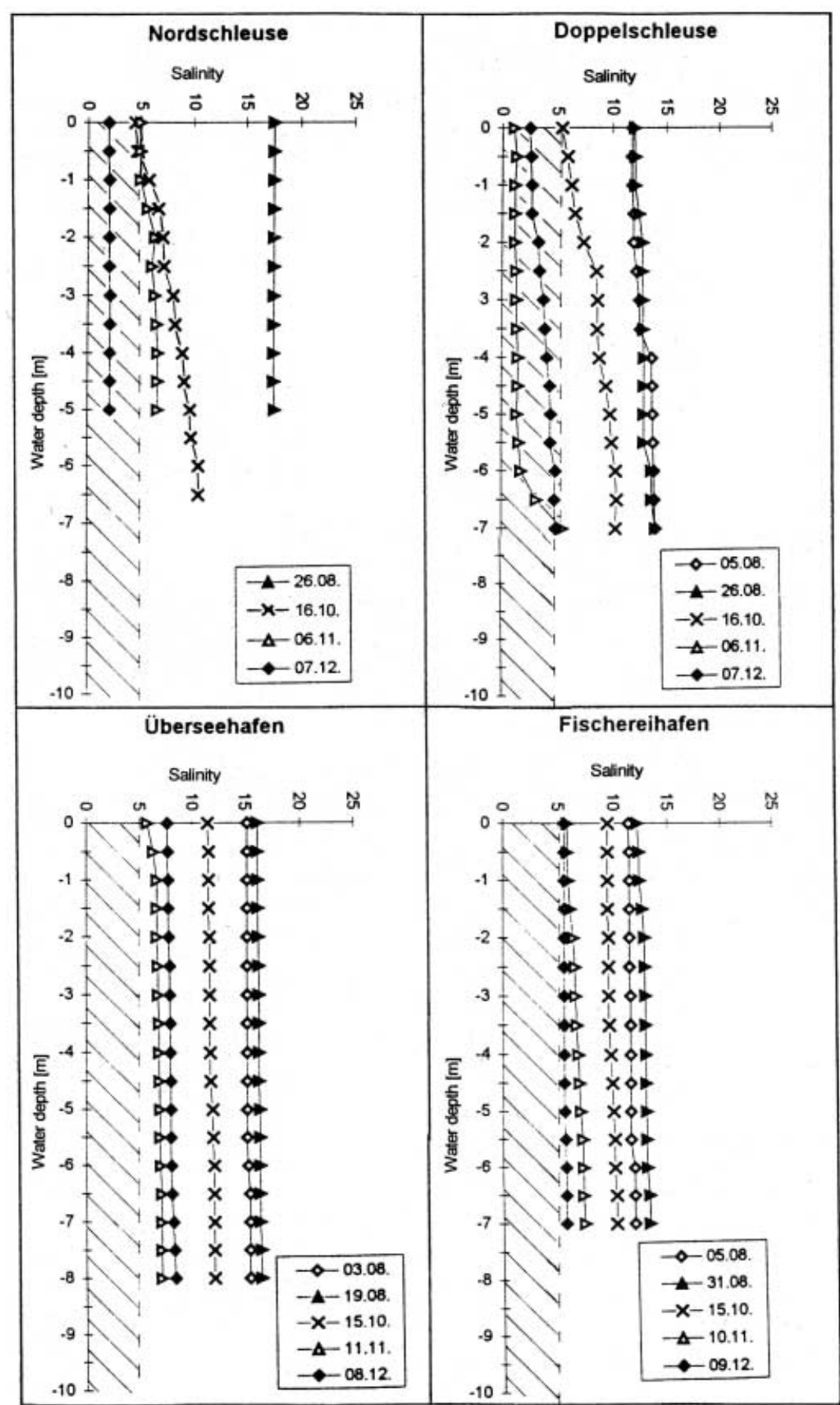

investigated, average tube counts also increased with water depth (Fig. 6), albeit not significantly (Spearman's rank correlation $\rho_{\mathrm{S}}=0.683, n=8, P=0.071$ ).

Shipworm spatfall on exposed fir panels

Actual shipworm infestation in 1998 was detected at three of 20 stations in the fir panels exposed from July to November (Fig. 1). The borehole densities in the infested panels were low, from 1 to 3 per panel (Table 3 ). There
Table 3 Shipworm borehole densities in fir panels $\left(0.06 \mathrm{~m}^{-2}\right)$ exposed in the harbours of Bremerhaven in 1998. In brackets number of boreholes in half panels with fouling (left), number of boreholes in half panels without fouling (right)

\begin{tabular}{lll}
\hline Location & Station & Number of boreholes per fir panel \\
\hline Überseehafen & $\ddot{U} 2$ & $3(1 / 2)$ \\
& Ü5 & $1(0 / 1)$ \\
Fischereihafen & F5 & $1(0 / 1)$ \\
\hline
\end{tabular}




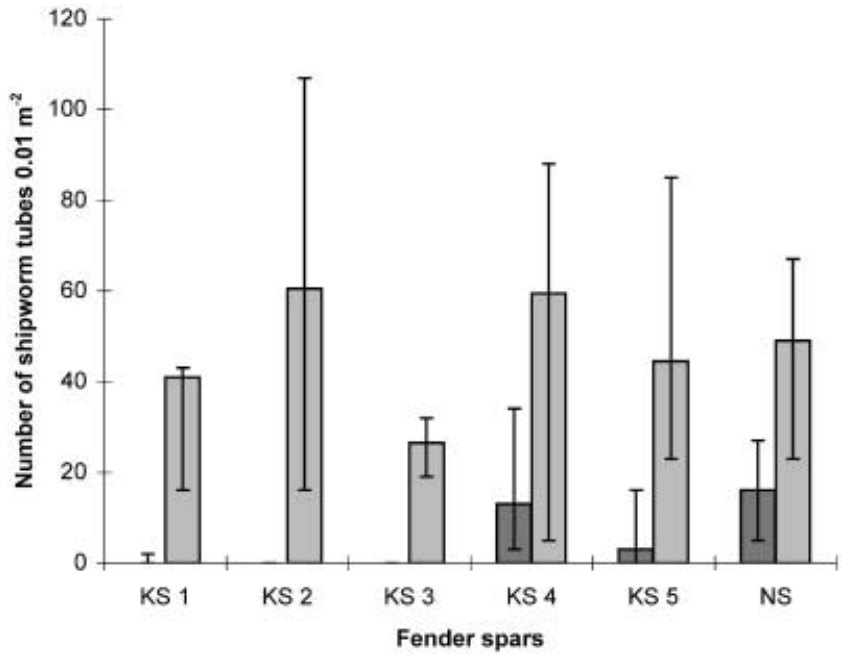

Fig. 4 Shipworm borehole densities in upper and lower planks of six floating fenders in two watergates of Bremerhaven harbours in 1998. $K S$ 1-5 five different floating fenders from the Kaiserschleuse; NS one floating fender from the Nordschleuse; dark bars median densities in upper planks, light bars median densities in lower planks; vertical lines depict the range between minimum and maximum values in each plank

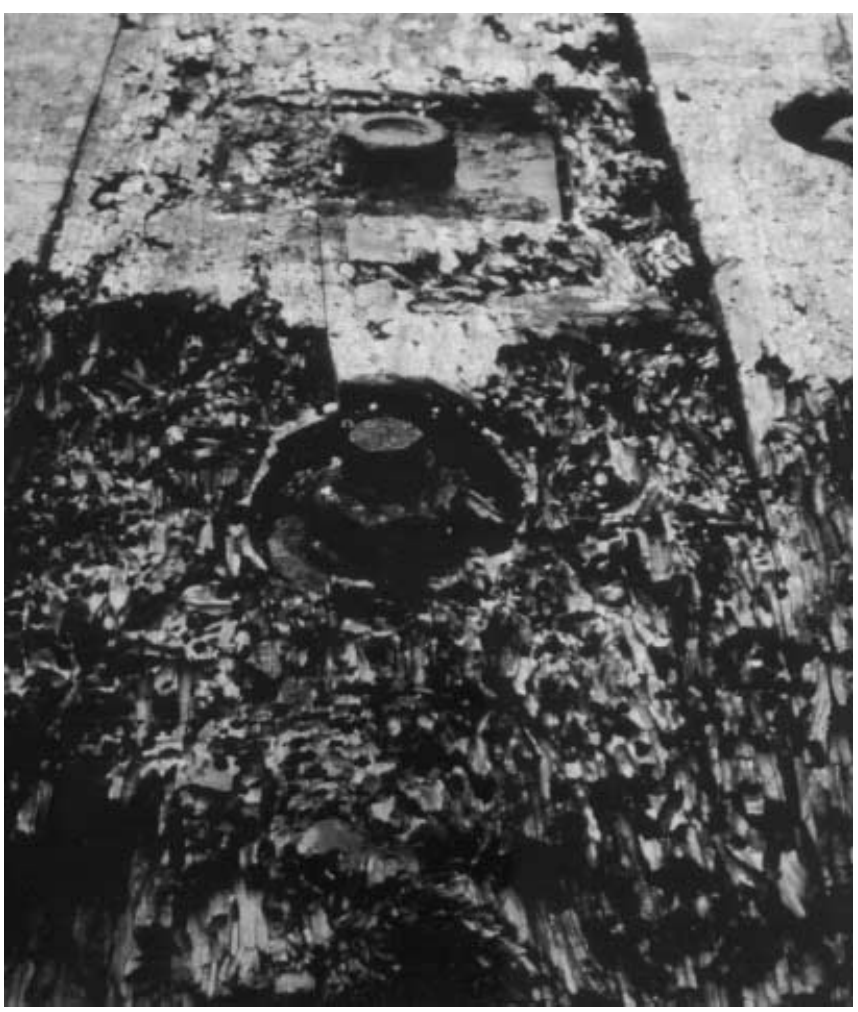

Fig. 5 Shipworm tubes in a lower plank of a floating fender from a watergate (Nordschleuse) in Bremerhaven harbours in 1998

were no clear infestation differences between panel halves which were regularly freed from epibionts and those which were not. X-ray photographs (Fig. 7) of the panels revealed that the body lengths of the shipworms

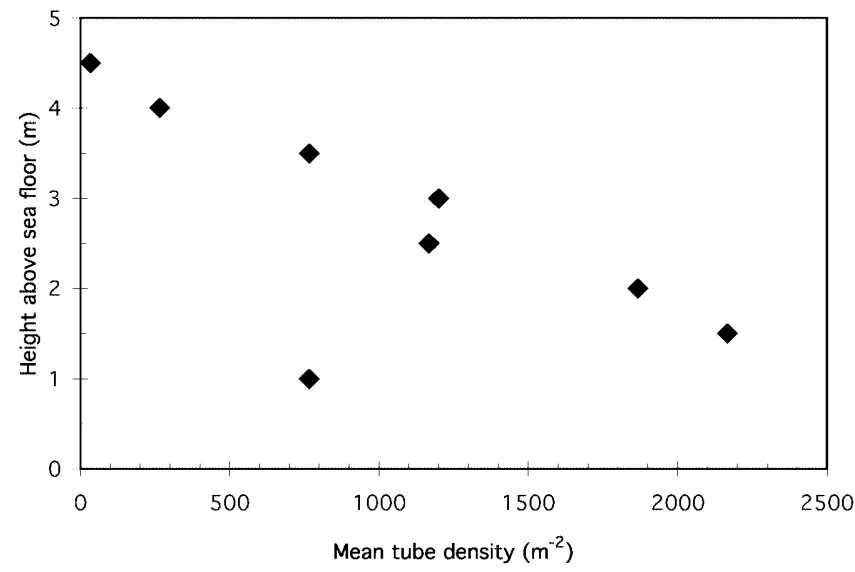

Fig. 6 Means of shipworm tube densities at different water depths (measured as height above sea floor) in an oak pile from a dock of the Überseehafen in Bremerhaven in 1998

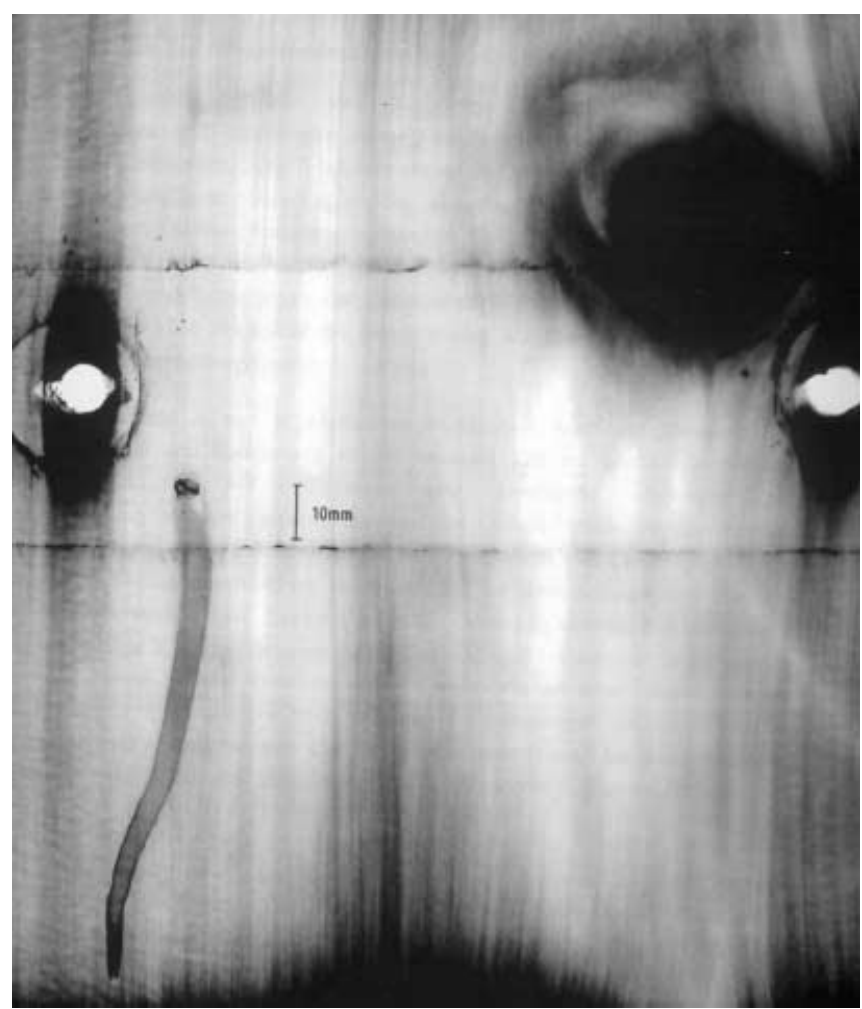

Fig. 7 X-ray photograph of a shipworm in an experimental fir panel exposed in a harbour dock (Fischereihafen) of Bremerhaven in 1998

which settled during the exposure period varied between 0.6 and $11.0 \mathrm{~cm}$.

\section{Discussion}

In the past, shipworms were thought to be absent in the estuaries of the German North Sea coast because average salinities below 9 should prevent a persistent colonisa- 
tion (Hahn 1956). In two studies (Roch 1927; Hahn 1956), the harbours of Bremerhaven were reported to be free of shipworm infestation, while this species was common off the coasts of both the North and Baltic Seas between Borkum and Warnemünde.

Besides the availability of wooden structures as settling substrates, the establishment of a shipworm population depends on the allochthonous import of larvae or adults through water currents, wooden ships or ballast water discharge or the successful spatfall of autochthonous larvae, which is primarily affected by the hydrographical regime (Turner 1966).

T. navalis is a euryhaline species and can, therefore, invade estuarine environments. It is known that this species thrives at salinities of 9 and higher (Blum 1922). Kühl (1957) attributed the mass occurrence of the common shipworm in the harbour of Cuxhaven from 1947 until 1949 to high salinities which remained above 15 for a long period of time. Successful reproduction has been reported for salinities above 10 (Schütz 1961; Soldatova 1961). At values below 7 , however, boring and feeding activities are markedly impeded while respiration is still continuing at a normal level. The animals can endure these adverse conditions for several weeks before starving to death (Roch 1940). At values below 5, siphon activities are completely stalled; the animals fall into a quiescent state and eventually die after a few days if salinities do not rise again (Blum 1922). The pelagic shipworm larvae are also known to die relatively quickly at salinities of less than 5 (Hoagland 1986).

Water temperatures of $15-25^{\circ} \mathrm{C}$ offer ideal living conditions for T. navalis. Below $10^{\circ} \mathrm{C}$, boring activities slow down, and they stop at values $<5^{\circ} \mathrm{C}$ (Roch 1932). At temperatures close to freezing point, the siphons are completely contracted, and the shipworms pass into a state of cold dormancy from which they can recover when temperatures increase (Roch 1932). With regard to levels and variability of temperature, $T$. navalis was denoted as being "very undemanding and tenacious" (Roch 1932). They can easily survive normal winters on the German coasts, and only extremely cold winters have led to distinct decreases or extinctions of shipworm populations.

In contrast to previous reports, we document here for the first time that live adult $T$. navalis do occur in Bremerhaven harbours. This is not surprising, as the locks and docks offer almost ideal living conditions for this shipworm species. There is an ample availability of wooden structures of various types (floating fenders, pier posts, piles). Furthermore, the salinities were higher than the critical levels of 9 and 5 throughout most of the year within the watergates and docks of both the Überseehafen and the Fischereihafen. As known from other investigations (Tabata and LeBrasseur 1958), salinities generally tend to be higher within harbour docks than in the adjacent estuaries. Therefore, harbours offer much better living conditions for shipworms.

Especially during summer, both temperature $\left(>18^{\circ} \mathrm{C}\right)$ and salinity $(>12)$ were relatively high in Bremerhaven in 1998. This certainly had a positive effect on the ship- worms' boring, feeding and reproduction rates. It is very likely that more than the one of the specimens we found during our study has produced larvae. During autumn and winter, hydrographic conditions deteriorated as temperatures and salinities decreased, partly even below the critical levels reported in scientific literature. However, although our measurements were not continued in 1999, it does not seem very likely that the low values persisted for a sufficiently long period of time and that the shipworm population as a whole was endangered.

We conclude from our results that the common shipworm T. navalis is currently a regular component of the anthropogenic estuarine ecosystems of the harbours of Bremerhaven. It encounters favourable conditions for growth and reproduction, at least during summer and autumn. Therefore, a persistent infestation of all wooden structures after a relatively short period of time seems to be highly probable. In 1998, the population densities were rather low in pier posts and piles but, given the static and economic importance of pier posts, it was alarming enough to find any shipworms at all inside the wood. Fender spars were heavily infested, and their mechanical stability was significantly impaired. A further dispersal of T. navalis in the docks of Bremerhaven and the occasional development of mass occurrences seems to be highly probable.

Acknowledgements This study was supported by the Port Authorities of Bremerhaven (Hansestadt Bremisches Hafenamt Bremerhaven). We would like to express our appreciation to all colleagues at Küstenökologische Forschungsgesellschaft $\mathrm{GmbH}$, especially to Dr Martine Marchand, Jan Witt and Silke Allers, for their support and assistance. We are very grateful for be able to gain access to the laboratories of the Alfred-Wegener-Institut Bremerhaven and particularly acknowledge the help of Dr Eike Rachor, Dr Bodil Bluhm and Michael Seebeck.

\section{References}

Benthem-Jütting T van (1943) Mollusca (I), C. Lamellibranchia (in Dutch). In: Boschma H (ed) Fauna van Nederland, Mollusca. Sijthoff's Uitgeversmaatschappij, Leiden, pp 397-421

Blum HF (1922) On the effect of low salinity on Teredo navalis. Univ Calif Publ Zool 22:350-368

Brockmann-Lehe C (1914) Brackwasserstudien. Sep Schr Ver Naturkunde 4:5-39

Crisp DJ, Jones LWG, Watson W (1953) Use of stereoscopy for examining shipworm infestation in vivo. Nature 172:408-409

Ghobashy AFA, Hassan AK (1980) Notes on the wood boring in the Suez Canal. In: Proceedings of the 5th international congress on marine corrosion and fouling. Biologia Marina, Barcelona, pp 93-98

Gollasch S (1996) Untersuchungen des Arteintrages durch den internationalen Schiffsverkehr unter besonderer Berücksichtigung nichtheimischer Arten. Verlag Dr Kovac, Hamburg

Hahn A (1956) Die Bekämpfung der Bohrmuschel. Küste 5:49-72

Hoagland KE (1986) Effects of temperature, salinity, and substratum on larvae of the shipworms Teredo bartschi Clapp and Teredo navalis Linnaeus (Bivalvia: Teredinidae). Am Malacol Bull 4:89-99

Kaestner A (1993) Lehrbuch der speziellen Zoologie 1(3), Wirbellose Tiere. Fischer, Jena, Germany

Kühl H (1957) Der Befall durch Bohrmuscheln und Bohrkrebse in Norderney, Wilhelmshaven, List a. Sylt und Kiel in den Jahren 1953-1955. Angew Zool 17:257-279 
Kühl H (1968) Schiffsbewuchs und Hafenbewuchs. Schiff Hafen 3:173-176

Kühl H (1972) Hydrography and biology of the Elbe estuary. Oceanogr Mar Biol Annu Rev 10:225-309

Nair NB, Saraswathy M (1971) The biology of wood-boring teredinid molluscs. Adv Mar Biol 9:335-509

Petersen C (1996) 100 Jahre Fischereihafen Bremerhaven. Nordwestdeutsche Verlagsgesellschaft, Bremerhaven

Reise K, Gollasch S, Wolff WJ (1999) Introduced marine species of the North Sea coasts. Helgol Meeresunters 52:219-234

Roch F (1927) Die Holz- und Steinschädlinge der Meeresküsten und ihre Bekämpfung. Veroeff Medizinalverw 24:1-78

Roch F (1932) Einige Beobachtungen zur Ökologie und Physiologie von Teredo navalis L. Ark Zool 24A:1-17

Roch F (1940) Die Terediniden des Mittelmeeres. Thalassia 4(3): $1-147$

Sachs L (1982) Angewandte Statistik. Springer, Berlin Heidelberg New York

Santhakumari V, Nair NB (1984) Vertical distribution of marine wood boring and fouling organisms from the estuarine areas of the South West coast of India. Fish Technol 21:118-125
Schütz L (1961) Verbreitung und Verbreitungsmöglichkeiten der Bohrmuschel Teredo navalis $\mathrm{L}$. und ihr Vordringen in den NO-Kanal bei Kiel. Kiel Meeresforschung 17:228-236

Soldatova IN (1961) Effect of various salinities on the bivalve mollusc Teredo navalis L. (in Russian). Trudy Inst Okeanol 49:162-179

Sordyl H, Bönsch R, Gercken J, Gosselck F, Kreuzberg M, Schulze H (1998) Verbreitung und Reproduktion des Schiffsbohrwurms Teredo navalis L. an der Küste MecklenburgVorpommerns. Dtsch Ges Meeresforsch 42:142-149

Tabata S, LeBrasseur RJ (1958) Sea water intrusion into the Frazer River and its relation to the incidence of shipworms in Steveston Cannery Bassin. J Fish Res Bd Canada 15:91-113

Tsunoda K (1979) Ecological studies of shipworm attack on wood in the sea water log storage side. Wood Res Inst Kyoto:11-53

Turner RD (1966) A survey and illustrated catalogue of the Teredinidae (Mollusca: Bivalvia). Museum of Comparative Zoology, Harvard University, Cambridge, Mass.

Turner RD (1971) Identification of marine wood boring molluscs of the world. In: Jones EBG, Eltringham SK (eds) Marine borers, fungi and fouling organisms. OECD, Paris, pp 18-64 